Check for updates

Cite this: RSC Adv., 2017, 7, 46866

Received 29th July 2017

Accepted 27th September 2017

DOI: $10.1039 / c 7 r a 08366 a$

rsc.li/rsc-advances

\title{
Water uptake and hygroscopicity of perchlorates and implications for the existence of liquid water in some hyperarid environments
}

\author{
Wenjun Gu, ${ }^{\text {ac }}$ Yongjie Li, ${ }^{b}$ Mingjin Tang, (D) *a Xiaohong Jia, ${ }^{\text {ac }}$ Xiang Ding, ${ }^{\text {a }}$ Xinhui $\mathrm{Bi}^{\mathrm{a}}$ \\ and Xinming Wang ${ }^{\text {ad }}$
}

The existence of liquid water is a prerequisite for habitability. Deliquescence of perchlorates under subsaturated conditions has been proposed to explain the occurrence of liquid water in some hyperarid environments on the earth and on the Mars. However, the amount of liquid water associated with perchlorates under different conditions is not well understood yet. In this work, we have measured deliquescence relative humidity (DRH) of three perchlorates at different temperatures from 278 to $303 \mathrm{~K}$. DRH decreases from $(42.8 \pm 0.6) \%$ at $278 \mathrm{~K}$ to $(40.5 \pm 0.5) \%$ at $303 \mathrm{~K}$ for $\mathrm{Mg}\left(\mathrm{ClO}_{4}\right)_{2} \cdot 6 \mathrm{H}_{2} \mathrm{O}$, and from $(18.5 \pm 0.5) \%$ at $278 \mathrm{~K}$ to $(15.5 \pm 0.5) \%$ at $303 \mathrm{~K}$ for $\mathrm{Ca}\left(\mathrm{ClO}_{4}\right)_{2} \cdot 4 \mathrm{H}_{2} \mathrm{O}$; in contrast, deliquescence of $\mathrm{KClO}_{4}$ did not occur even when $\mathrm{RH}$ (relative humidity) was increased to $95 \%$. In addition, we have determined the amount of water taken up by $\mathrm{Ca}\left(\mathrm{ClO}_{4}\right)_{2} \cdot 4 \mathrm{H}_{2} \mathrm{O}$ and $\mathrm{Mg}\left(\mathrm{ClO}_{4}\right)_{2} \cdot 6 \mathrm{H}_{2} \mathrm{O}$ as a function of $\mathrm{RH}(0-90 \%)$ and temperatures (278-298 K). It is found that when both salts are deliquesced, more water ( $10 \%$ on average) is associated with $\mathrm{Mg}\left(\mathrm{ClO}_{4}\right)_{2} \cdot 6 \mathrm{H}_{2} \mathrm{O}$ than $\mathrm{Ca}\left(\mathrm{ClO}_{4}\right)_{2} \cdot 4 \mathrm{H}_{2} \mathrm{O}$ on the per mole $\mathrm{ClO}_{4}{ }^{-}$base. Overall, this work would significantly improve our knowledge in hygroscopicity of perchlorates, and thus may provide fundamental insights into the hydrologic cycles in some hyperarid regions on the earth and on the Mars.

\section{Introduction}

As we currently understand, liquid water is a prerequisite for the occurrence of life. In hyperarid environments on the earth such as the Atacama Desert in Chile, pure liquid water is not stable due to extremely low water vapor concentrations in the atmosphere. ${ }^{1-3}$ Deliquescence of soluble minerals, such as chlorates and perchlorates, could lead to the formation of stable aqueous solution (and thus liquid water) in these hyperarid regions., ${ }^{2,-6}$ Deliquescence is the phenomenon that under subsaturated conditions a soluble component takes up water vapor and forms a stable aqueous solution. ${ }^{7}$ Indeed, perchlorates have been found in soils in many arid and/or semi-arid regions on the earth, including the Antarctic Dry Valleys, Southwest US, and the Atacama Desert. ${ }^{8-12}$ Perchlorates may be formed photochemically from chlorides and emitted by anthropogenic activities, ${ }^{8,11,13-15}$ but their sources are not entirely clear.

aState Key Laboratory of Organic Geochemistry, Guangdong Key Laboratory of Environmental Protection and Resources Utilization, Guangzhou Institute of Geochemistry, Chinese Academy of Sciences, Guangzhou 510640, China. E-mail: mingjintang@gig.ac.cn

${ }^{b}$ Department of Civil and Environmental Engineering, Faculty of Science and Technology, University of Macau, Avenida da Universidade, Taipa, Macau, China

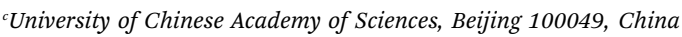

${ }^{d}$ Center for Excellence in Regional Atmospheric Environment, Institute of Urban Environment, Chinese Academy of Sciences, Xiamen 361021, China
The deliquescence of perchlorates is also relevant for the Martian environment. One important question in research of the Mars is whether liquid water exists or existed on the Mars. Evidence which supports the existence of liquid water on the Mars is mounting, ${ }^{16-18}$ though pure liquid water is not stable on the Mars due to its extremely dry and cold environment as well as low atmospheric pressure. It has been proposed that the presence of perchlorates in Martian soil, which have been detected at a number of sites on the Mars, ${ }^{19,20}$ can lower the freezing temperature of liquid water and form stable aqueous solutions by absorbing water vapor from the atmosphere even under subsaturated conditions. ${ }^{21-25}$

Several laboratory and theoretical studies have investigated the deliquescence and efflorescence of perchlorates at different temperatures..$^{22,23,25-28}$ For example, a laboratory study by Zorzano et al. ${ }^{23}$ found that sodium perchlorate could absorb water vapor and form aqueous solutions under Martian conditions at temperatures as low as $225 \mathrm{~K}$. The deliquescence relative humidity (DRH) decreases from $64 \%$ at $223 \mathrm{~K}$ to $42 \%$ at $273 \mathrm{~K}$ for $\mathrm{Mg}\left(\mathrm{ClO}_{4}\right)_{2} \cdot 6 \mathrm{H}_{2} \mathrm{O}$, and decreases from $64 \%$ at $228 \mathrm{~K}$ to $51 \%$ at $273 \mathrm{~K}$ for $\mathrm{NaClO}_{4} \cdot \mathrm{H}_{2} \mathrm{O}^{25}$ The DRH of calcium perchlorate varies between $5 \%$ and $55 \%$ for the temperature range of $223-273 \mathrm{~K},{ }^{22}$ probably because the hydration state of calcium perchlorate changes at different temperatures. It has not been clearly stated in the two original studies ${ }^{22,25}$ whether the $\mathrm{RH}$ was respected to liquid water or ice, though $\mathrm{RH}$ with respect to liquid water is 
commonly used for $\mathrm{DRH}^{7}$ In another study using a Raman scattering lidar, ${ }^{26} \mathrm{Mg}\left(\mathrm{ClO}_{4}\right)_{2} \cdot 6 \mathrm{H}_{2} \mathrm{O}$ was found to deliquesce when the temperature is only $\sim 4 \mathrm{~K}$ higher than the frost point. Phase transition of chloride-perchlorate binary mixtures and the salt analog, which closely replicates the composition and relative concentrations of common cations and anions found at the Phoenix landing site on Mars, has also been explored. ${ }^{29,30}$ While previous studies support the possible occurrence of liquid water in some hyperarid regions on the earth (as well as on the Mars) from a fundamental point of view, a better understanding of hydrologic cycles in these hyperarid environments requires quantitative knowledge of water partitioning between the gas phase and perchlorates under different conditions. However, to our knowledge such information is not available yet.

In this work we have quantitatively measured the amount of water associated with $\mathrm{Ca}\left(\mathrm{ClO}_{4}\right)_{2} \cdot 4 \mathrm{H}_{2} \mathrm{O}, \mathrm{Mg}\left(\mathrm{ClO}_{4}\right)_{2} \cdot 6 \mathrm{H}_{2} \mathrm{O}$ and $\mathrm{KClO}_{4}$ in equilibrium with water vapor as a function of $\mathrm{RH}$ (0-90\%) at different temperatures (278-298 K). In addition, we have also determined the DRH of $\mathrm{Ca}\left(\mathrm{ClO}_{4}\right)_{2} \cdot 4 \mathrm{H}_{2} \mathrm{O}$ and $\mathrm{Mg}\left(\mathrm{ClO}_{4}\right)_{2} \cdot 6 \mathrm{H}_{2} \mathrm{O}$ as a function of temperature $(278-303 \mathrm{~K})$ in a very accurate manner. Our results provide quantitative knowledge of deliquescence properties of perchlorates, and thus may help better understand the hydrologic cycles in some hyperarid environments on the earth and on the Mars.

\section{Experimental section}

The interaction of perchlorates with water vapor under subsaturated conditions was investigated using a commercial vapor sorption analyzer (model no. Q5000SA; manufacturer: TA Instruments, New Castle, DE, USA). The instrument has been detailed in our previous study, ${ }^{\mathbf{3 1}}$ and here we only briefly describe experimental procedures that are important for this study. High purity $\mathrm{N}_{2}$ was used in this work unless otherwise stated.

\subsection{Vapor sorption analyzer}

The schematic diagram of the vapor sorption analyzer used in this work is shown in Fig. 7 in the Appendix. The principle of this instrument lies on accurate and precise measurements of the absolute mass of the sample under investigation at well controlled temperature and RH. A humidity chamber was used to control the temperature and $\mathrm{RH}$ under which the sample was exposed to water vapor. $\mathrm{RH}$ was regulated by mixing a dry $\mathrm{N}_{2}$ flow with a humidified $\mathrm{N}_{2}$ flow, both controlled using mass flow controllers (MFC), and the total flow delivered into the humidity chamber was set to $200 \mathrm{~mL} \mathrm{~min}^{-1}$. Temperature $(278-353 \mathrm{~K}$ ) and RH (0-98\%) to which perchlorates were exposed could be programmed and were monitored in real time as well. Temperature stability of $\pm 0.1 \mathrm{~K}$ and $\mathrm{RH}$ stability of $\pm 1 \%$ could be achieved. In this work all the experiments were conducted under isothermal conditions, i.e. during each experiments temperature was kept constant while $\mathrm{RH}$ was varied.

Two semispherical metalized quartz crucibles, connected to a high-precision balance via hang-down wires, were located in the humidity chamber. These crucibles, each with a volume of $180 \mu \mathrm{L}$, were provided by the instrument manufacturer. One crucible contained perchlorate powder and the other one was empty, and therefore water uptake by the empty crucible could be simultaneously measured and subtracted. The balance used to measure sample mass has a dynamic range of 0-100 $\mathrm{mg}$, a stated sensitivity of $<0.1 \mu \mathrm{g}$, and a weighing accuracy of $\pm 0.1 \mu \mathrm{g}$. The baseline drift in mass measurement was found to be $<5 \mu \mathrm{g}$ within $24 \mathrm{~h}$ at $20 \% \mathrm{RH}$ and $298 \mathrm{~K}$ when no sample was used for the sample crucible. A small $\mathrm{N}_{2}$ flow $\left(10 \mathrm{~mL} \mathrm{~min}^{-1}\right)$ was used to purge the balance continuously in order to prevent moisture condensation. In this work the initial mass of perchlorate samples was typically in the range of $1-5 \mathrm{mg}$, and in each experiments fresh perchlorate samples were used. Since only data under equilibrium were used, the amount of sample should not impact our results; however, it affected the time to reach the equilibrium (i.e. it took longer to reach the equilibrium if the initial mass of the sample was larger).

\subsection{Water uptake measurements}

In the first type of experiments, the amounts of water associated with perchlorates were determined as a function of $\mathrm{RH}$ at different temperatures. The following experimental procedures were used: (i) temperature was set to a given value; (2) after the temperature was stabilized, the sample was dried at $0 \% \mathrm{RH}$ (the actual RH was measured to be $<5 \%$ under "dry" conditions) until the mass change was $<0.05 \%$ within $30 \mathrm{~min}$; (3) RH was increased stepwise to $90 \%$ with an increment of $10 \%$ per step, and at each RH the sample was equilibrated with water vapor until its mass became stable (i.e. the sample mass change was $<0.1 \%$ within $30 \mathrm{~min}$ ); (4) the sample was dried again at $0 \% \mathrm{RH}$ until its mass change was $<0.1 \%$ within $30 \mathrm{~min}$.

Fig. 1 shows the dataset for a typical experiment designed to measure the amount of water taken up by $\mathrm{Ca}\left(\mathrm{ClO}_{4}\right)_{2} \cdot 4 \mathrm{H}_{2} \mathrm{O}$ as

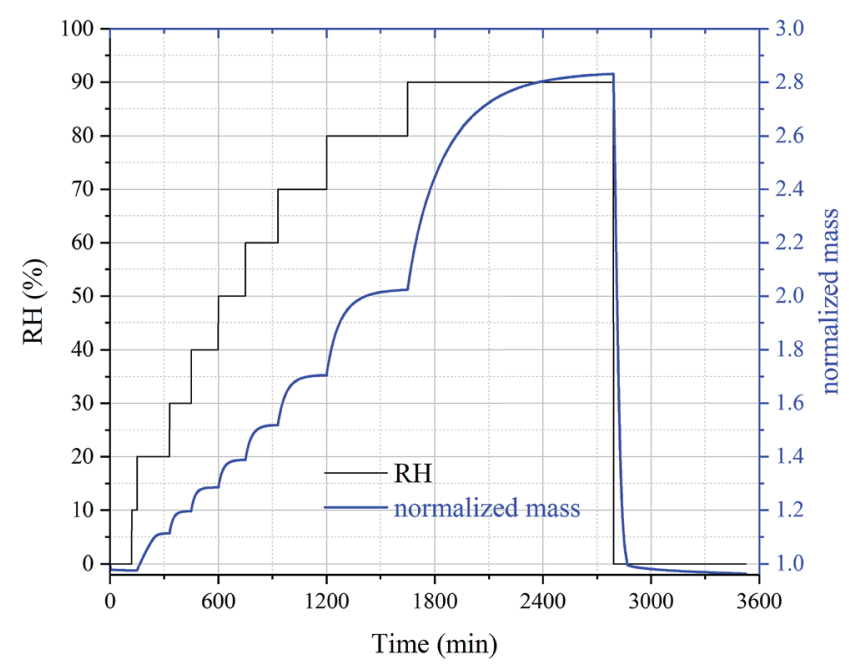

Fig. 1 Time series of $\mathrm{RH}$ and normalized sample mass in a typical experiment designed to measure mass hygroscopic growth factors of perchlorates. In the experiment shown in this figure, $\mathrm{Ca}\left(\mathrm{ClO}_{4}\right)_{2} \cdot 4 \mathrm{H}_{2} \mathrm{O}$ was used and the temperature was set to $298 \mathrm{~K}$. 
a function of $\mathrm{RH}$ at $298 \mathrm{~K}$. Significant increase in sample mass was observed when $\mathrm{RH}$ was increased from $10 \%$ to $20 \%$, suggesting that the deliquescence of $\mathrm{Ca}\left(\mathrm{ClO}_{4}\right)_{2} \cdot 4 \mathrm{H}_{2} \mathrm{O}$ occurred at a RH between $10 \%$ and $20 \%$ at $298 \mathrm{~K}$. Further increase in $\mathrm{RH}$ caused additional increase in sample mass. After $\mathrm{RH}$ was returned to $0 \%$, the sample mass was equal to the initial value within the experimental uncertainty, suggesting that after the humidification-dehumidification process, the sample had the same hydration state as the unprocessed one. The data shown in Fig. 1 could be used to derive the amounts of water taken up by $\mathrm{Ca}\left(\mathrm{ClO}_{4}\right)_{2} \cdot 4 \mathrm{H}_{2} \mathrm{O}$ as a function of $\mathrm{RH}$.

\subsection{DRH determination}

Accurate DRH values were measured in the second set of experiments as a function of temperature for perchlorates, and the following experimental procedures were used: (1) temperature was set to a given value; (2) after the temperature was stabilized, the sample was dried at $0 \% \mathrm{RH}$ until the mass change was $<0.05 \%$ within $30 \mathrm{~min}$; (3) RH was then increased to a value which was at least $5 \%$ lower than the expected DRH (which could be roughly estimated from experiments described in Section 2.2) and kept at this level for $60 \mathrm{~min}$; (4) RH was increased stepwise with an increment of $1 \%$ per step until a significant increase in sample mass occurred, and at each $\mathrm{RH}$ the sample was equilibrated with the environment for $30 \mathrm{~min}$. DRH is equal to the RH at which a significant increase in sample mass was observed (i.e. the mass increase was significant compared to the noise level and baseline drift).

Fig. 2 shows the time series of sample mass and $\mathrm{RH}$ in an experiment to measure DRH of $\mathrm{Ca}\left(\mathrm{ClO}_{4}\right)_{2} \cdot 4 \mathrm{H}_{2} \mathrm{O}$ at $298 \mathrm{~K}$. As shown in Fig. 2, a slow and small decrease in sample mass was observed when RH was increased from $0 \%$ to $16 \%$, suggesting that gradual loss of residual water, which may be adsorbed by

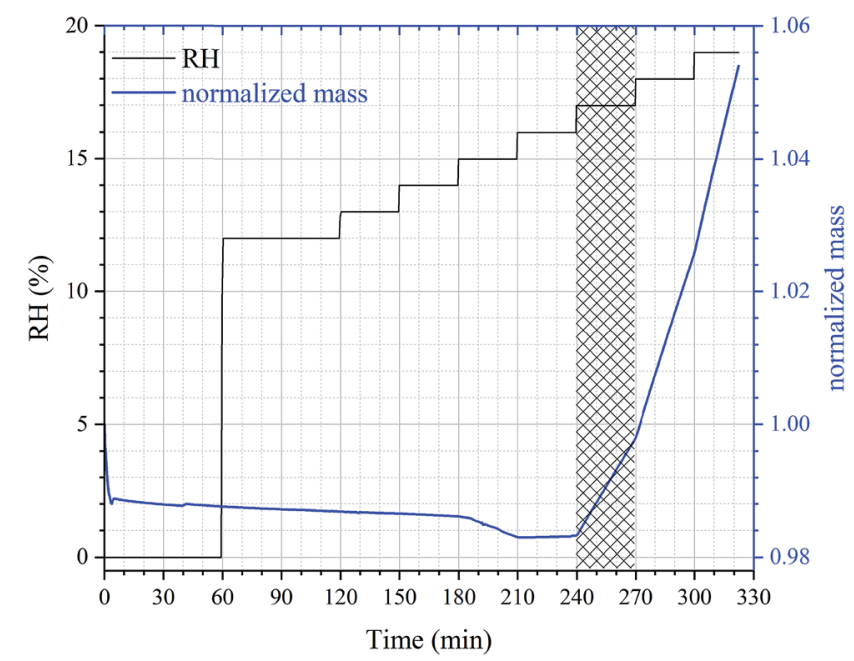

Fig. 2 Time series of $\mathrm{RH}$ and normalized sample mass in a typical experiment designed to measure $\mathrm{DRH}$ of perchlorates. In the experiment shown in this figure, $\mathrm{Ca}\left(\mathrm{ClO}_{4}\right)_{2} \cdot 4 \mathrm{H}_{2} \mathrm{O}$ was used and the temperature was set to $298 \mathrm{~K}$. The shadowed region shows the $\mathrm{RH}$ at which a significant increase in sample mass was first observed due to deliquescence of $\mathrm{Ca}\left(\mathrm{ClO}_{4}\right)_{2} \cdot 4 \mathrm{H}_{2} \mathrm{O}$. the powdered $\mathrm{Ca}\left(\mathrm{ClO}_{4}\right)_{2} \cdot 4 \mathrm{H}_{2} \mathrm{O}$ sample, occurred before it was deliquesced. When RH was increased from $16 \%$ to $17 \%$ (shadowed region in Fig. 2), a significant increase in sample mass was observed, suggesting that the DRH of $\mathrm{Ca}\left(\mathrm{ClO}_{4}\right)_{2} \cdot 4 \mathrm{H}_{2} \mathrm{O}$ was measured to be $(16.5 \pm 0.5) \%$ (strictly speaking, between $16 \%$ and $17 \%$ ). Fig. 2 also reveals that when RH was above the DRH, further increase in $\mathrm{RH}$ would lead to quicker increase in sample mass, as expected.

\section{Results and discussion}

In this work we have studied water uptake by $\mathrm{Ca}\left(\mathrm{ClO}_{4}\right)_{2} \cdot 4 \mathrm{H}_{2} \mathrm{O}$, $\mathrm{Mg}\left(\mathrm{ClO}_{4}\right)_{2} \cdot 6 \mathrm{H}_{2} \mathrm{O}$ and $\mathrm{KClO}_{4}$, because previous studies suggested $^{22,32-35}$ that they are the most stable forms of $\mathrm{Ca}\left(\mathrm{ClO}_{4}\right)_{2}$, $\mathrm{Mg}\left(\mathrm{ClO}_{4}\right)_{2}$ and $\mathrm{KClO}_{4}$ for the temperature range $(278-303 \mathrm{~K})$ covered by our work. $\mathrm{Ca}\left(\mathrm{ClO}_{4}\right)_{2} \cdot 4 \mathrm{H}_{2} \mathrm{O}, \mathrm{Mg}\left(\mathrm{ClO}_{4}\right)_{2} \cdot 6 \mathrm{H}_{2} \mathrm{O}$ and $\mathrm{KClO}_{4}$ were provided by Aldrich with stated purity of $>99 \%$. All the chemicals were used as received without any pretreatment.

\subsection{DRH of perchlorates}

$\mathrm{DRH}$ values were determined as a function of temperature from 278 to $303 \mathrm{~K}$ for $\mathrm{Ca}\left(\mathrm{ClO}_{4}\right)_{2} \cdot 4 \mathrm{H}_{2} \mathrm{O}$ and $\mathrm{Mg}\left(\mathrm{ClO}_{4}\right)_{2} \cdot 6 \mathrm{H}_{2} \mathrm{O}$, and the results are summarized in Table 1 . The $\mathrm{DRH}$ of $\mathrm{Mg}\left(\mathrm{ClO}_{4}\right)_{2} \cdot 6 \mathrm{H}_{2} \mathrm{O}$ was found to slightly decrease with increasing temperature, from $(42.8 \pm 0.6) \%$ at $278 \mathrm{~K}$ to $(40.5 \pm 0.5) \%$ at $303 \mathrm{~K}$. DRH of $\mathrm{Mg}\left(\mathrm{ClO}_{4}\right)_{2} \cdot 6 \mathrm{H}_{2} \mathrm{O}$ was measured to be $42 \%$ at $273 \mathrm{~K}$ by a previous study by Gough et al.,$^{25}$ and it increased to $64 \%$ when temperature decreased to $223 \mathrm{~K}$. The DRH measured at $273 \mathrm{~K}$ by Gough et al. ${ }^{25}$ is in good agreement with that measured at $278 \mathrm{~K}$ in our work. In addition, our measured DRH values and their dependence on temperature are also consistent with those calculated using a thermodynamic mode ${ }^{25}$ for temperature in the range of 278-303 K. The thermodynamic model used by Gough et al. $^{25}$ and Nuding et al. ${ }^{22}$ was developed by Chevrier et al. ${ }^{24}$ In brief, this thermodynamic model, in which the Pitzer ion interaction mode ${ }^{36}$ was used to calculate activities of water and different ions, calculated the stability diagram of perchlorates as a function of solute concentration and temperature. ${ }^{24}$

For comparison, DRH of $\mathrm{Ca}\left(\mathrm{ClO}_{4}\right)_{2} \cdot 4 \mathrm{H}_{2} \mathrm{O}$ is much lower than that of $\mathrm{Mg}\left(\mathrm{ClO}_{4}\right)_{2} \cdot 6 \mathrm{H}_{2} \mathrm{O}$ at the same temperature. In addition, a weak negative dependence of $\mathrm{DRH}$ on temperature was also observed for $\mathrm{Ca}\left(\mathrm{ClO}_{4}\right)_{2} \cdot 4 \mathrm{H}_{2} \mathrm{O}$, with $\mathrm{DRH}$ increasing from (15.5

Table 1 Deliquescence relative humidities (DRH) of $\mathrm{Ca}\left(\mathrm{ClO}_{4}\right)_{2} \cdot 4 \mathrm{H}_{2} \mathrm{O}$ and $\mathrm{Mg}\left(\mathrm{ClO}_{4}\right)_{2} \cdot 6 \mathrm{H}_{2} \mathrm{O}$ at different temperatures $(278-303 \mathrm{~K})$. All the measurements were repeated three times, and the stated errors $( \pm 1 \sigma)$ are statistical only

\begin{tabular}{|c|c|c|}
\hline & DRH (\%) & DRH (\%) \\
\hline$T(\mathrm{~K})$ & $\mathrm{Ca}\left(\mathrm{ClO}_{4}\right)_{2} \cdot 4 \mathrm{H}_{2} \mathrm{O}$ & $\mathrm{Mg}\left(\mathrm{ClO}_{4}\right)_{2} \cdot 6 \mathrm{H}_{2} \mathrm{O}$ \\
\hline 278 & $18.5 \pm 0.5$ & $42.8 \pm 0.6$ \\
\hline 283 & $17.5 \pm 0.5$ & $42.2 \pm 0.6$ \\
\hline 288 & $17.5 \pm 0.5$ & $41.5 \pm 0.5$ \\
\hline 293 & $16.5 \pm 0.5$ & $41.2 \pm 0.6$ \\
\hline 298 & $16.5 \pm 0.5$ & $40.5 \pm 0.5$ \\
\hline 303 & $16.5 \pm 0.5$ & $40.5 \pm 0.5$ \\
\hline
\end{tabular}


$\pm 0.5) \%$ to $(18.5 \pm 0.5) \%$ when temperature decreases from 303 to $278 \mathrm{~K}$. The DRH of calcium perchlorate was measured to be $(10 \pm 4) \%$ at $273 \mathrm{~K}$ and $(55 \pm 4) \%$ at $223 \mathrm{~K}$ by Nuding et al. ${ }^{22}$ and the large variation in DRH at different temperatures was suggested to result from the formation of different hydrates at different temperatures. Our measured DRH ( 18.5\%) at $278 \mathrm{~K}$ is slightly higher than that measured at $273 \mathrm{~K}(\sim 10 \%)$ by Nuding et al. ${ }^{22}$ Furthermore, it appears that compared to DRH measured by Nuding et al., ${ }^{22}$ our reported values agree better with those predicted by their thermodynamic model.

It is suggested that the dependence of DRH on temperature can be approximated by the Clausius-Clapeyron equation: $:^{37-39}$

$$
\ln [\operatorname{DRH}(T)]=\ln [\operatorname{DRH}(298)]+\frac{A \Delta H_{\mathrm{s}}}{R}\left(\frac{1}{T}-\frac{1}{298}\right)
$$

where $\operatorname{DRH}(T)$ and $\operatorname{DRH}(298)$ is the DRH at the temperature of $T$ and $298 \mathrm{~K}, A$ is a dimensionless constant dependent on the solubility of the salt in water, $R$ is gas constant $\left(\mathrm{J} \mathrm{mol}^{-1} \mathrm{~K}^{-1}\right)$, and $\Delta H_{\mathrm{s}}$ is the enthalpy of solution $\left(\mathrm{J} \mathrm{mol}^{-1}\right)$. Eqn (1) implies that plotting $\ln (\mathrm{DRH})$ versus $1 / T$ would generates a straight line, with its slope equal to $A \Delta H_{\mathrm{S}} / R$. This is confirmed by the data shown in Fig. 3, and the slopes are found to be $587 \pm 96 \mathrm{~K}$ for $\mathrm{Ca}\left(\mathrm{ClO}_{4}\right)_{2}$. $4 \mathrm{H}_{2} \mathrm{O}$ and $198 \pm 18 \mathrm{~K}$ for $\mathrm{Mg}\left(\mathrm{ClO}_{4}\right)_{2} \cdot 6 \mathrm{H}_{2} \mathrm{O}$, respectively.

The interaction of water vapor with $\mathrm{KClO}_{4}$ was also explored at 278 and $298 \mathrm{~K}$. As shown in Fig. 4, $\mathrm{KClO}_{4}$ did not take up significant amount of water even when $\mathrm{RH}$ was increased from $0 \%$ to $95 \%$. This observation suggests that the $\mathrm{DRH}$ of $\mathrm{KClO}_{4}$ is above $95 \%$ for the temperature range (278-303 K) covered in our work. This is qualitatively consistent with the low solubility of $\mathrm{KClO}_{4}$ in water $\left(\sim 2.1 \mathrm{~g} \mathrm{KClO}_{4}\right.$ in $100 \mathrm{~g}$ water $)$ at $298 \mathrm{~K}$ reported by Willard and Smith. ${ }^{40}$

\subsection{Mass hygroscopic growth factors of perchlorates}

We have further measured the mass hygroscopic growth factors (defined as the ratio of sample mass at a given $\mathrm{RH}$ to that at $0 \%$ $\mathrm{RH})$ as a function of $\mathrm{RH}$ at three different temperatures (278,

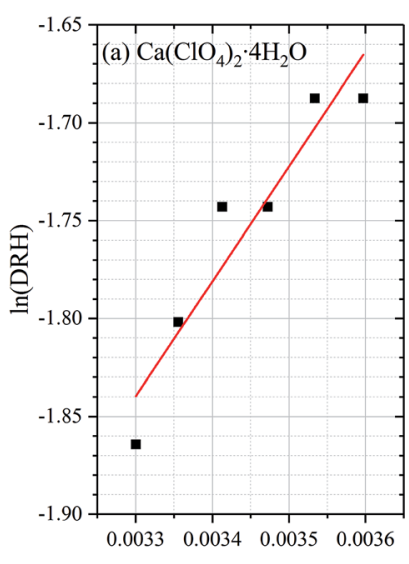

$1 / T\left(\mathrm{~K}^{-1}\right)$

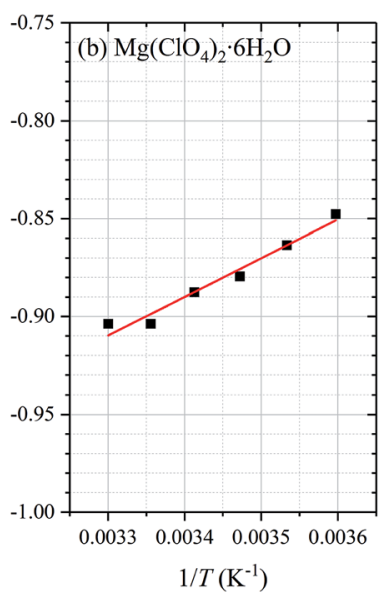

$1 / T\left(\mathrm{~K}^{-1}\right)$
Fig. 3 Dependence of deliquescence relative humidities (DRH) of (a) $\mathrm{Ca}\left(\mathrm{ClO}_{4}\right)_{2} \cdot 4 \mathrm{H}_{2} \mathrm{O}$ and (b) $\mathrm{Mg}\left(\mathrm{ClO}_{4}\right)_{2} \cdot 6 \mathrm{H}_{2} \mathrm{O}$ on temperature in the range of 278-303 K. As suggested by eqn (1), plotting $\ln (\mathrm{DRH})$ versus $1 / T$ would generate a straight line, and the two red lines represent the fitted linear lines.

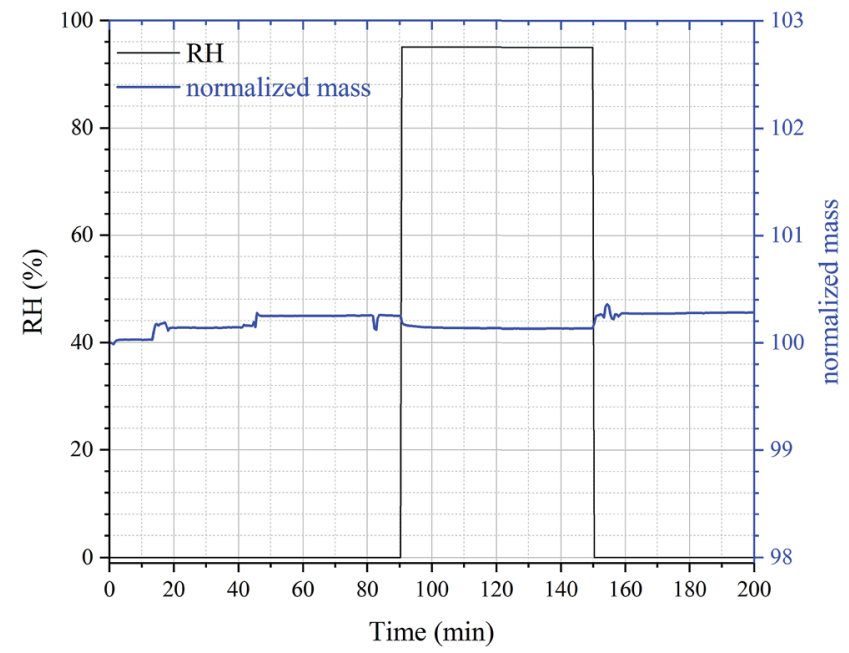

Fig. 4 Time series of $\mathrm{RH}$ and normalized sample mass in an experiment designed to measure the mass hygroscopic growth factors of $\mathrm{KClO}_{4}$ at $278 \mathrm{~K}$. No significant change in sample mass was observed when $\mathrm{RH}$ was increased from $0 \%$ to $95 \%$, suggesting that the $\mathrm{DRH}$ of $\mathrm{KClO}_{4}$ was $>95 \%$. Additional experiments were carried out at $298 \mathrm{~K}$, and the $\mathrm{DRH}$ of $\mathrm{KClO}_{4}$ was also found to be $>95 \%$ at $298 \mathrm{~K}$.

288 and $298 \mathrm{~K}$ ). The results are compiled in Table 2. To our knowledge, the amount of water associated with $\mathrm{Ca}\left(\mathrm{ClO}_{4}\right)_{2}$. $4 \mathrm{H}_{2} \mathrm{O}$ under well controlled conditions has never been reported, and quantitative information for $\mathrm{Mg}\left(\mathrm{ClO}_{4}\right)_{2} \cdot 6 \mathrm{H}_{2} \mathrm{O}$ is also very limited.

As shown in Table 2 and Fig. $5, \mathrm{Ca}\left(\mathrm{ClO}_{4}\right)_{2} \cdot 4 \mathrm{H}_{2} \mathrm{O}$ undergoes deliquescence when $\mathrm{RH}$ was increased from $10 \%$ to $20 \%$, and deliquescence occurred for $\mathrm{Mg}\left(\mathrm{ClO}_{4}\right)_{2} \cdot 6 \mathrm{H}_{2} \mathrm{O}$ when $\mathrm{RH}$ was increased from $40 \%$ to $50 \%$. This is consistent with their measured DRH values (see Section 3.1). After deliquesced, both $\mathrm{Ca}\left(\mathrm{ClO}_{4}\right)_{2} \cdot 4 \mathrm{H}_{2} \mathrm{O}$ and $\mathrm{Mg}\left(\mathrm{ClO}_{4}\right)_{2} \cdot 6 \mathrm{H}_{2} \mathrm{O}$ could take up significant amount of water under subsaturated conditions. For example, due to absorption of water vapor from the gas phase at $298 \mathrm{~K}$, the mass of $\mathrm{Ca}\left(\mathrm{ClO}_{4}\right)_{2} \cdot 4 \mathrm{H}_{2} \mathrm{O}$ was increased by $\sim 44 \%$ at $50 \% \mathrm{RH}$, $\sim 77 \%$ at $70 \% \mathrm{RH}$, and $\sim 190 \%$ at $90 \% \mathrm{RH}$, respectively, compared to the initial mass at $0 \% \mathrm{RH}$. It is also observed that at a given $\mathrm{RH}$, decrease in temperature will increase the amounts of water associated with deliquesced $\mathrm{Ca}\left(\mathrm{ClO}_{4}\right)_{2} \cdot 4 \mathrm{H}_{2} \mathrm{O}$ and $\mathrm{Mg}\left(\mathrm{ClO}_{4}\right)_{2} \cdot 6 \mathrm{H}_{2} \mathrm{O}$. Toner et al. ${ }^{41}$ showed that from a thermodynamic point of view, for a given solute concentration, decrease in temperature would lead to decrease in water activity; in other words, for the same water activity (i.e. at a given $\mathrm{RH}$ ), decrease in temperature would cause decrease in solute concentration, and thus increase in mass ratio of water to solute ratio and increase in mass growth factors. Therefore, our experimental measurement is consistent with theoretical prediction by Toner et al. ${ }^{41}$

Water to solute ratio (WSR), defined as the molar ratio of $\mathrm{H}_{2} \mathrm{O}$ to $\mathrm{ClO}_{4}{ }^{-}$, can be calculated from the measured mass hygroscopic growth factors, and the results are displayed in Fig. 6. Note that $\mathrm{RH}$ in Fig. 6 is plotted on the scale of $0-1$ instead of $0-100 \%$. Aqueous water in the solution formed due to deliquescence of $\mathrm{Mg}\left(\mathrm{ClO}_{4}\right)_{2} \cdot 6 \mathrm{H}_{2} \mathrm{O}$ or $\mathrm{Ca}\left(\mathrm{ClO}_{4}\right)_{2} \cdot 4 \mathrm{H}_{2} \mathrm{O}$ comes from two sources: (i) water absorbed from the gas phase and (ii) 
Table 2 Mass hygroscopic growth factors (defined as the ratio of the sample mass at a given $\mathrm{RH}$ to that at $0 \% \mathrm{RH}$ ) of $\mathrm{Ca}\left(\mathrm{ClO}_{4}\right)_{2} \cdot 4 \mathrm{H}_{2} \mathrm{O}$ and $\mathrm{Mg}\left(\mathrm{ClO}_{4}\right)_{2} \cdot 6 \mathrm{H}_{2} \mathrm{O}$ as a function of $\mathrm{RH}$ at 278,288 and $298 \mathrm{~K}$. Measurements at $298 \mathrm{~K}$ were repeated three times to ensure the reproducibility, and the shown errors $( \pm 1 \sigma)$ are statistical only. Only one measurement was carried out for each of other conditions, because the reproducibility at $298 \mathrm{~K}$ was very good and duration of each individual measurement was rather long at 278 and $288 \mathrm{~K}$ (typically 4-7 days)

\begin{tabular}{|c|c|c|c|c|c|c|}
\hline \multirow[b]{2}{*}{$\mathrm{RH}(\%)$} & \multicolumn{3}{|l|}{$\underline{\mathrm{Ca}\left(\mathrm{ClO}_{4}\right)_{2} \cdot 4 \mathrm{H}_{2} \mathrm{O}}$} & \multicolumn{3}{|l|}{$\underline{\mathrm{Mg}}\left(\mathrm{ClO}_{4}\right)_{2} \cdot 6 \mathrm{H}_{2} \mathrm{O}$} \\
\hline & $298 \mathrm{~K}$ & $288 \mathrm{~K}$ & $278 \mathrm{~K}$ & $298 \mathrm{~K}$ & $288 \mathrm{~K}$ & $278 \mathrm{~K}$ \\
\hline 10 & $0.9998 \pm 0.0002$ & 0.9998 & 0.9997 & $0.9996 \pm 0.0001$ & 0.9995 & 0.9996 \\
\hline 20 & $1.1573 \pm 0.0326$ & 1.1988 & 1.2122 & $0.9991 \pm 0.0003$ & 0.9991 & 0.9993 \\
\hline 30 & $1.2434 \pm 0.0355$ & 1.2872 & 1.3021 & $0.9988 \pm 0.0003$ & 0.9988 & 0.9990 \\
\hline 60 & $1.5778 \pm 0.0436$ & 1.6364 & 1.6585 & $1.5788 \pm 0.0074$ & 1.5868 & 1.6085 \\
\hline 70 & $1.7714 \pm 0.0463$ & 1.8392 & 1.8664 & $1.7767 \pm 0.0081$ & 1.7902 & 1.8132 \\
\hline 80 & $2.1004 \pm 0.0499$ & 2.1895 & 2.2325 & $2.1184 \pm 0.0094$ & 2.1401 & 2.1852 \\
\hline 90 & $2.9241 \pm 0.0349$ & 3.0777 & 3.2687 & $2.9876 \pm 0.0132$ & 3.0677 & 3.2277 \\
\hline
\end{tabular}

water released by $\mathrm{Mg}\left(\mathrm{ClO}_{4}\right)_{2} \cdot 6 \mathrm{H}_{2} \mathrm{O}$ or $\mathrm{Ca}\left(\mathrm{ClO}_{4}\right)_{2} \cdot 4 \mathrm{H}_{2} \mathrm{O}$ once dissolved. It can be concluded that after both salts were deliquesced (for $\mathrm{RH}$ at $50 \%$ and above), more water $(\sim 10 \%$ on average) was associated with $\mathrm{Mg}\left(\mathrm{ClO}_{4}\right)_{2} \cdot 6 \mathrm{H}_{2} \mathrm{O}$ than $\mathrm{Ca}\left(\mathrm{ClO}_{4}\right)_{2}$. $4 \mathrm{H}_{2} \mathrm{O}$ on the per mole $\mathrm{ClO}_{4}{ }^{-}$base. A recent thermodynamic model study ${ }^{42}$ suggests that for a given perchlorate concentration in molality $\left(\mathrm{mol} \mathrm{kg}^{-1}\right)$, water activity of $\mathrm{Mg}\left(\mathrm{ClO}_{4}\right)_{2}$ solution is slightly larger than that for $\mathrm{Ca}\left(\mathrm{ClO}_{4}\right)_{2}$. Since water activity decreases with solute concentration, this implies that for a given water activity, the molality concentration is smaller for $\mathrm{Mg}\left(\mathrm{ClO}_{4}\right)_{2}$. In other words, the theoretical work by Toner et al. ${ }^{42}$ also suggested that at a given $\mathrm{RH}$ more water is associated with $\mathrm{Mg}\left(\mathrm{ClO}_{4}\right)_{2}$ than $\mathrm{Ca}\left(\mathrm{ClO}_{4}\right)_{2}$ on the per mole $\mathrm{ClO}_{4}{ }^{-}$base.

As shown in Fig. 6, the dependence of WSR on RH at $298 \mathrm{~K}$ for both $\mathrm{Ca}\left(\mathrm{ClO}_{4}\right)_{2} \cdot 4 \mathrm{H}_{2} \mathrm{O}$ and $\mathrm{Mg}\left(\mathrm{ClO}_{4}\right)_{2} \cdot 6 \mathrm{H}_{2} \mathrm{O}$ can be fitted using the following polynomial equation: ${ }^{43}$

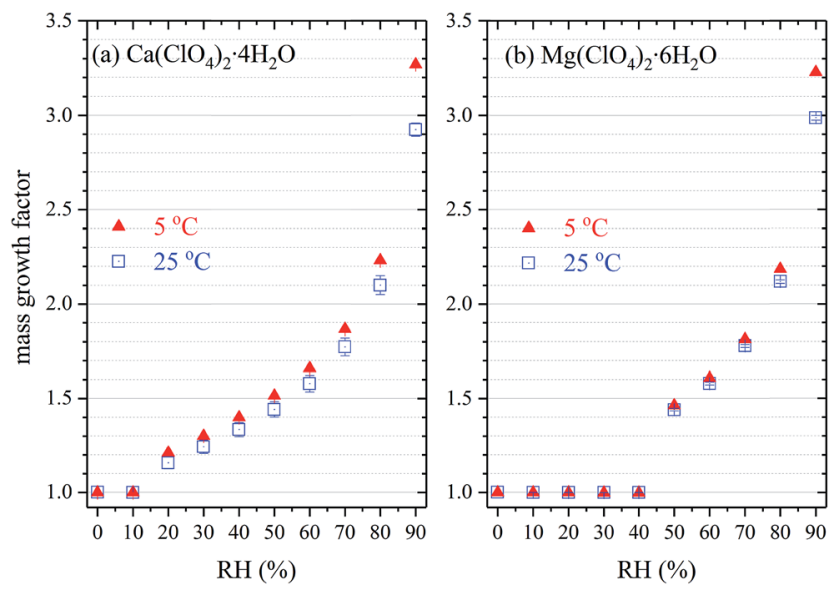

Fig. 5 Mass hygroscopic growth factors of (a) $\mathrm{Ca}\left(\mathrm{ClO}_{4}\right)_{2} \cdot 4 \mathrm{H}_{2} \mathrm{O}$ and (b) $\mathrm{Mg}\left(\mathrm{ClO}_{4}\right)_{2} \cdot 6 \mathrm{H}_{2} \mathrm{O}$ as a function of $\mathrm{RH}$ at 278 (triangles) and $298 \mathrm{~K}$ (squares). Measurements were also carried out at $288 \mathrm{~K}$, and the results are not displayed in this figure for better readability (but included in Table 2).

$$
\mathrm{WSR}=k_{0}+k_{1} R H+k_{2} R H^{2}+k_{3} R H^{3}+k_{4} R H^{4}
$$

It is further found that the WSR data at 288 and $278 \mathrm{~K}$ can also be fitted using eqn (2), and the polynomial coefficients obtained are summarized in Table 3 for both salts at three different temperatures.

At $20 \% \mathrm{RH} \mathrm{Ca}\left(\mathrm{ClO}_{4}\right)_{2} \cdot 4 \mathrm{H}_{2} \mathrm{O}$ was deliquesced to form a solution with WSR of $\sim 3.82$, which should be slightly larger than that for saturated solution (a saturated solution should be formed at the RH equal to DRH, which was determined to be $\sim 16.5 \%$ at $298 \mathrm{~K}$ ). Similarly, when RH increased from $40 \%$ to $50 \%, \mathrm{Mg}\left(\mathrm{ClO}_{4}\right)_{2} \cdot 6 \mathrm{H}_{2} \mathrm{O}$ underwent deliquescence and formed a solution with $n\left(\mathrm{H}_{2} \mathrm{O}\right) / n\left(\mathrm{ClO}_{4}{ }^{-}\right)$of $\sim 7.26$, which should also be slightly larger than that for saturated solution. The solubility was determined to be $188.6 \mathrm{~g}$ per $100 \mathrm{~g} \mathrm{H}_{2} \mathrm{O}$ for anhydrous $\mathrm{Ca}\left(\mathrm{ClO}_{4}\right)_{2}$ and $99.6 \mathrm{~g}$ per $100 \mathrm{~g} \mathrm{H}_{2} \mathrm{O}$ for anhydrous $\mathrm{Mg}\left(\mathrm{ClO}_{4}\right)_{2}$ at

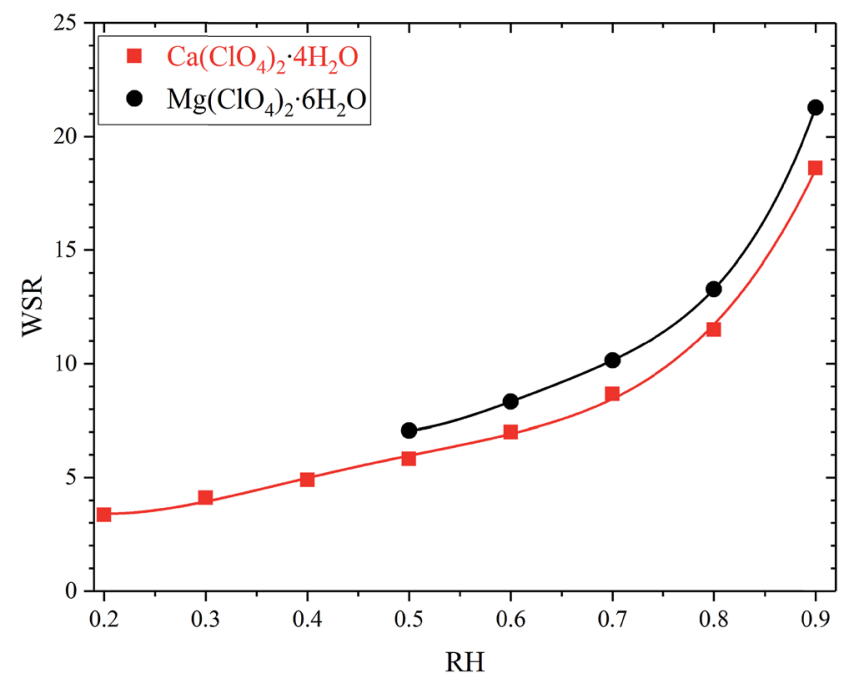

Fig. 6 Water to solute ratio (WSR), defined as the molar ratios of $\mathrm{H}_{2} \mathrm{O}$ to $\mathrm{ClO}_{4}{ }^{-}$, as a function of $\mathrm{RH}$ for $\mathrm{Ca}\left(\mathrm{ClO}_{4}\right)_{2} \cdot 4 \mathrm{H}_{2} \mathrm{O}$ and $\mathrm{Mg}\left(\mathrm{ClO}_{4}\right)_{2}$. $6 \mathrm{H}_{2} \mathrm{O}$ after deliquescence at $298 \mathrm{~K}$. The two curves show the polynomial fittings to the experimental data, as described by eqn (2). 
Table 3 Polynomial coefficients obtained when using eqn (2) to fit the WSR data measured in this work as a function of $\mathrm{RH}$ for $\mathrm{Ca}\left(\mathrm{ClO}_{4}\right)_{2} \cdot 4 \mathrm{H}_{2} \mathrm{O}$ and $\mathrm{Mg}\left(\mathrm{ClO}_{4}\right)_{2} \cdot 6 \mathrm{H}_{2} \mathrm{O}$ at three different temperatures. Note that in this work WSR is defined as the molar ratio of $\mathrm{H}_{2} \mathrm{O}$ to $\mathrm{ClO}_{4}{ }^{-}$in deliquesced salts

\begin{tabular}{|c|c|c|c|c|c|c|}
\hline$T(\mathrm{~K})$ & $k_{0}$ & $k_{1}$ & $k_{2}$ & $k_{3}$ & $k_{4}$ & Valid RH range \\
\hline \multicolumn{7}{|c|}{$\mathrm{Ca}\left(\mathrm{ClO}_{4}\right)_{2} \cdot 4 \mathrm{H}_{2} \mathrm{O}$} \\
\hline 298 & 8.982 & -68.613 & 280.385 & -431.422 & 241.907 & $0.2-0.9$ \\
\hline 288 & 10.027 & -76.214 & 309.064 & -474.868 & 265.622 & $0.2-0.9$ \\
\hline 278 & 12.644 & -102.880 & 406.286 & -619.776 & 341.669 & $0.2-0.9$ \\
\hline \multicolumn{7}{|c|}{$\mathrm{Mg}\left(\mathrm{ClO}_{4}\right)_{2} \cdot 6 \mathrm{H}_{2} \mathrm{O}$} \\
\hline 298 & 174.765 & -1103.441 & 2676.955 & -2855.798 & 1147.936 & $0.5-0.9$ \\
\hline 288 & 207.530 & -1309.148 & 3157.012 & -3349.155 & 1336.810 & $0.5-0.9$ \\
\hline 278 & 228.714 & -1455.690 & 3534.575 & -3775.969 & 1515.893 & $0.5-0.9$ \\
\hline
\end{tabular}

$298 \mathrm{~K},{ }^{40}$ corresponding to WSR of 3.52 for saturated $\mathrm{Ca}\left(\mathrm{ClO}_{4}\right)_{2}$ solution and 6.22 for saturated $\mathrm{Mg}\left(\mathrm{ClO}_{4}\right)_{2}$ solution. Therefore, our measured WSR values are consistent with those derived from solubility measurements. Zhang and Chan et al. ${ }^{27}$ utilized an electrodynamic balance coupled with Raman spectroscopy to determine water to solute molar ratios as a function of $\mathrm{RH}$ at room temperature. Comparison of our results at $298 \mathrm{~K}$ with those presented graphically by Zhang and $\mathrm{Chan}^{27}$ suggests a reasonably good agreement.

\section{Conclusions and implications}

The deliquescence behaviors of perchlorates under subsaturated conditions are suggested to be the reason why liquid water can exist in some hyperarid regions on the earth. In this study we have measured the DRH of $\mathrm{Ca}\left(\mathrm{ClO}_{4}\right)_{2} \cdot 4 \mathrm{H}_{2} \mathrm{O}, \mathrm{Mg}\left(\mathrm{ClO}_{4}\right)_{2}-$ $\cdot 6 \mathrm{H}_{2} \mathrm{O}$ and $\mathrm{KClO}_{4}$ in the temperature range of $278-303 \mathrm{~K}$. While the DRH of $\mathrm{KClO}_{4}$ is above $95 \%, \mathrm{Ca}\left(\mathrm{ClO}_{4}\right)_{2} \cdot 4 \mathrm{H}_{2} \mathrm{O}$ and $\mathrm{Mg}\left(\mathrm{ClO}_{4}\right)_{2} \cdot 6 \mathrm{H}_{2} \mathrm{O}$ are found to deliquesce at much lower $\mathrm{RH}$. More specifically, the DRH of $\mathrm{Mg}\left(\mathrm{ClO}_{4}\right)_{2} \cdot 6 \mathrm{H}_{2} \mathrm{O}$ decreases from $(42.8 \pm 0.6) \%$ at $278 \mathrm{~K}$ to $(40.5 \pm 0.5) \%$ at $303 \mathrm{~K}$, and it decreases from $(18.5 \pm 0.5) \%$ at $278 \mathrm{~K}$ to $(15.5 \pm 0.5) \%$ at $303 \mathrm{~K}$ for $\mathrm{Ca}\left(\mathrm{ClO}_{4}\right)_{2} \cdot 4 \mathrm{H}_{2} \mathrm{O}$, both exhibiting a slightly negative dependence on temperature. Therefore, our work confirms that liquid water can exist as perchlorate solutions at temperatures relevant for the earth even when RH is much lower than $100 \%$.

More importantly, we have quantitatively measured the amount of water associated with $\mathrm{Ca}\left(\mathrm{ClO}_{4}\right)_{2} \cdot 4 \mathrm{H}_{2} \mathrm{O}$ and $\mathrm{Mg}\left(\mathrm{ClO}_{4}\right)_{2} \cdot 6 \mathrm{H}_{2} \mathrm{O}$ as a function of $\mathrm{RH}$ at $278-298 \mathrm{~K}$. It is found that when both salts are deliquesced, under the same condition more water $(\sim 10 \%$ on average $)$ is associated with $\mathrm{Mg}\left(\mathrm{ClO}_{4}\right)_{2}$. $6 \mathrm{H}_{2} \mathrm{O}$ than $\mathrm{Ca}\left(\mathrm{ClO}_{4}\right)_{2} \cdot 4 \mathrm{H}_{2} \mathrm{O}$ on the per mole $\mathrm{ClO}_{4}{ }^{-}$base. Our work would significantly improve our knowledge in hygroscopic properties of perchlorates, and therefore could help us better understand the hydrological cycles in some hyperarid environments on the earth, such as the Atacama Desert in Chile.

Most of the time the Mars is extremely cold with typical temperature at $200-220 \mathrm{~K}$; however, the temperature around the Martian equator in the summer can reach $>280 \mathrm{~K},{ }^{21}$ overlapping with the temperature range our current work covers. Therefore, our work may also be relevant for the possible existence of liquid water on the Mars. In addition, experiments at Martian relevant temperatures are difficult and thermodynamic models are widely used for prediction and interpretation; $;, 24,25$ as a result, the comprehensive and systematical dataset obtained at $278-303 \mathrm{~K}$ for $\mathrm{Mg}\left(\mathrm{ClO}_{4}\right)_{2} \cdot 6 \mathrm{H}_{2} \mathrm{O}, \mathrm{Ca}\left(\mathrm{ClO}_{4}\right)_{2} \cdot 4 \mathrm{H}_{2} \mathrm{O}$ and $\mathrm{KClO}_{4}$ in our work could be used to constrain and verify these thermodynamic models. We are also developing a new instrument which would be able to measure hygroscopicity of perchlorates at much lower temperatures.

\section{Conflicts of interest}

There are no conflicts to declare.

\section{Appendix}

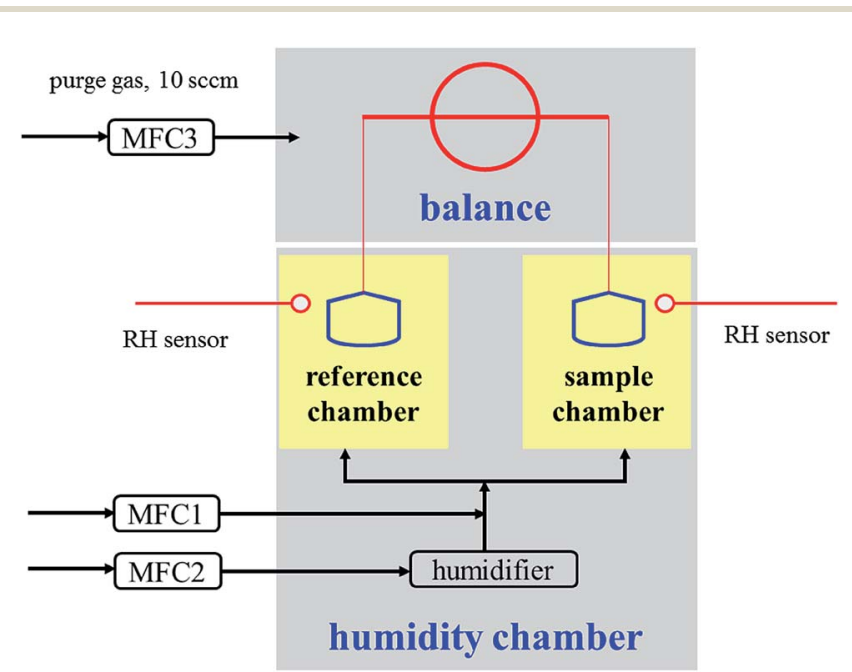

Fig. 7 Schematic diagram of the vapor sorption analyzer used in this work. MFC1, MFC2 and MFC3 were mass flow controllers.

\section{Acknowledgements}

This work is financially supported by Chinese National Science Foundation (grant No. 91644106 and 41675120), the Chinese Academy of Sciences international collaborative project (grant No. 132744KYSB20160036), the Science and Technology 
Development Fund of Macau (136/2016/A3), and State Key Laboratory of Organic Geochemistry (grant No. SKLOGA201603A). Mingjin Tang would like to thank the CAS Pioneer Hundred Talents program for providing a starting grant. This is contribution No. IS-2443 from GIGCAS.

\section{References}

1 R. Navarro-Gonzalez, F. A. Rainey, P. Molina, D. R. Bagaley, B. J. Hollen, J. de la Rosa, A. M. Small, R. C. Quinn, F. J. Grunthaner, L. Czaceres, B. Gomez-Silva and C. P. McKay, Science, 2003, 302, 1018-1021.

2 A. F. Davila, B. Gómez-Silva, A. de los Rios, C. Ascaso, H. Olivares, C. P. McKay and J. Wierzchos, J. Geophys. Res.: Biogeosci., 2008, 113, G01028, DOI: 10.01029/02007jg000561.

3 C. P. McKay, E. I. Friedmann, B. Gomez-Silva, L. CaceresVillanueva, D. T. Andersen and R. Landheim, Astrobiology, 2003, 3, 393-406.

4 J. Levy, A. Fountain, W. B. Lyons and K. Welch, Antarct. Sci., 2015, 27, 163-171.

5 R. V. Gough, V. F. Chevrier and M. A. Tolbert, Planet. Space Sci., 2016, 131, 79-87.

6 A. F. Davila, I. Hawes, C. Ascaso and J. Wierzchos, Environ. Microbiol. Rep., 2013, 5, 583-587.

7 S. T. Martin, Chem. Rev., 2000, 100, 3403-3453.

8 D. C. Catling, M. W. Claire, K. J. Zahnle, R. C. Quinn, B. C. Clark, M. H. Hecht and S. Kounaves, J. Geophys. Res.: Planets, 2010, 115, E00E11, DOI: 10.1029/2009je003425.

9 S. P. Kounaves, S. T. Stroble, R. M. Anderson, Q. Moore, D. C. Catling, S. Douglas, C. P. McKay, D. W. Ming, P. H. Smith, L. K. Tamppari and A. P. Zent, Environ. Sci. Technol., 2010, 44, 2360-2364.

10 B. Rao, T. A. Anderson, G. J. Orris, K. A. Rainwater, S. Rajagopalan, R. M. Sandvig, B. R. Scanlon, D. A. Stonestrom, M. A. Walvoord and W. A. Jackson, Environ. Sci. Technol., 2007, 41, 4522-4528.

11 D. R. Parker, Environ. Chem., 2009, 6, 10-27.

12 P. K. DasGupta, J. V. Dyke, A. B. Kirk and W. A. Jackson, Environ. Sci. Technol., 2006, 40, 6608-6614.

13 B. L. Carrier and S. P. Kounaves, Geophys. Res. Lett., 2015, 42, 3739-3745.

14 S. P. Kounaves, B. L. Carrier, G. D. O'Neil, S. T. Stroble and M. W. Claire, Icarus, 2014, 229, 206-213.

15 S. P. Kounaves, N. A. Chaniotakis, V. F. Chevrier, B. L. Carrier, K. E. Folds, V. M. Hansen, K. M. McElhoney, G. D. O'Neil and A. W. Weber, Icarus, 2014, 232, 226-231.

16 A. S. McEwen, L. Ojha, C. M. Dundas, S. S. Mattson, S. Byrne, J. J. Wray, S. C. Cull, S. L. Murchie, N. Thomas and V. C. Gulick, Science, 2011, 333, 740-743.

17 A. S. McEwen, C. M. Dundas, S. S. Mattson, A. D. Toigo, L. Ojha, J. J. Wray, M. Chojnacki, S. Byrne, S. L. Murchie and N. Thomas, Nat. Geosci., 2014, 7, 53-58.

18 L. Ojha, M. B. Wilhelm, S. L. Murchie, A. S. McEwen, J. J. Wray, J. Hanley, M. Masse and M. Chojnacki, Nat. Geosci., 2015, 8, 829-832.

19 L. A. Leshin, P. R. Mahaffy, C. R. Webster, M. Cabane, P. Coll, P. G. Conrad, P. D. Archer, S. K. Atreya, A. E. Brunner,
A. Buch, J. L. Eigenbrode, G. J. Flesch, H. B. Franz, C. Freissinet, D. P. Glavin, A. C. McAdam, K. E. Miller, D. W. Ming, R. V. Morris, R. Navarro-Gonzalez, P. B. Niles, T. Owen, R. O. Pepin, S. Squyres, A. Steele, J. C. Stern, R. E. Summons, D. Y. Sumner, B. Sutter, C. Szopa, S. Teinturier, M. G. Trainer, J. J. Wray, J. P. Grotzinger and M. S. L. S. Team, Science, 2013, 341, 1238937, DOI: 10.1231126/science.1238937.

20 D. W. Ming, P. D. Archer, D. P. Glavin, J. L. Eigenbrode, H. B. Franz, B. Sutter, A. E. Brunner, J. C. Stern, C. Freissinet, A. C. McAdam, P. R. Mahaffy, M. Cabane, P. Coll, J. L. Campbell, S. K. Atreya, P. B. Niles, J. F. Bell, D. L. Bish, W. B. Brinckerhoff, A. Buch, P. G. Conrad, D. J. Des Marais, B. L. Ehlmann, A. G. Fairen, K. Farley, G. J. Flesch, P. Francois, R. Gellert, J. A. Grant, J. P. Grotzinger, S. Gupta, K. E. Herkenhoff, J. A. Hurowitz, L. A. Leshin, K. W. Lewis, S. M. McLennan, K. E. Miller, J. Moersch, R. V. Morris, R. Navarro-Gonzalez, A. A. Pavlov, G. M. Perrett, I. Pradler, S. W. Squyres, R. E. Summons, A. Steele, E. M. Stolper, D. Y. Sumner, C. Szopa, S. Teinturier, M. G. Trainer, A. H. Treiman, D. T. Vaniman, A. R. Vasavada, C. R. Webster, J. J. Wray, R. A. Yingst and M. S. L. S. Team, Science, 2014, 343, 1245267, DOI: 10.1241126/science.1245267.

21 F. J. Martin-Torres, M.-P. Zorzano, P. Valentin-Serrano, A.-M. Harri, M. Genzer, O. Kemppinen, E. G. RiveraValentin, I. Jun, J. Wray, M. Bo Madsen, W. Goetz, A. S. McEwen, C. Hardgrove, N. Renno, V. F. Chevrier, M. Mischna, R. Navarro-Gonzalez, J. Martinez-Frias, P. Conrad, T. McConnochie, C. Cockell, G. Berger, A. R. Vasavada, D. Sumner and D. Vaniman, Nat. Geosci., 2015, 8, 357-361.

22 D. L. Nuding, E. G. Rivera-Valentin, R. D. Davis, R. V. Gough, V. F. Chevrier and M. A. Tolbert, Icarus, 2014, 243, 420-428.

23 M. P. Zorzano, E. Mateo-Marti, O. Prieto-Ballesteros, S. Osuna and N. Renno, Geophys. Res. Lett., 2009, 36, L20201, DOI: 10.21029/22009gl040315.

24 V. F. Chevrier, J. Hanley and T. S. Altheide, Geophys. Res. Lett., 2009, 36, L10202, DOI: 10.11029/12009gl037497.

25 R. V. Gough, V. F. Chevrier, K. J. Baustian, M. E. Wise and M. A. Tolbert, Earth Planet. Sci. Lett., 2011, 312, 371-377.

26 G. Nikolakakos and J. A. Whiteway, Geophys. Res. Lett., 2015, 42, 7899-7906.

27 Y. H. Zhang and C. K. Chan, J. Phys. Chem. A, 2003, 107, 5956-5962.

28 E. Fischer, G. M. Martinez and N. O. Renno, Astrobiology, 2016, 16, 937-948.

29 R. V. Gough, V. F. Chevrier and M. A. Tolbert, Earth Planet. Sci. Lett., 2014, 393, 73-82.

30 D. L. Nuding, R. D. Davis, R. V. Gough and M. A. Tolbert, J. Geophys. Res.: Planets, 2015, 120, 588-598.

31 W. J. Gu, Y. J. Li, J. X. Zhu, X. H. Jia, Q. H. Lin, G. H. Zhang, X. Ding, W. Song, X. H. Bi, X. M. Wang and M. J. Tang, Atmos. Meas. Tech., 2017, DOI: 10.5194/amt-2017-5156.

32 O. N. Pestova, L. A. Myund, M. K. Khripun and A. V. Prigaro, Russ. J. Appl. Chem., 2005, 78, 409-413. 
33 T. A. Dobrynina, N. A. Akhapkina and V. Y. Rosolovskii, Russ. J. Inorg. Chem., 1984, 29, 1818-1822.

34 K. Robertson and D. Bish, J. Geophys. Res.: Planets, 2011, 116, E07006, DOI: 10.01029/02010je003754.

35 D. J. Devlin and P. J. Herley, Thermochim. Acta, 1986, 104, 159-178.

36 K. S. Pitzer, Activity Coefficients in Electrolyte Solutions, CRC Press, Boca Raton, Florida, USA, 1991.

37 A. S. Wexler and J. H. Seinfeld, Atmos. Environ., 1991, 25, 2731-2748.
38 J. H. Seinfeld and S. N. Pandis, Atmospheric Chemistry and Physics: From Air Pollution to Climate Change, Wiley Interscience, New York, 2006.

39 G. Zeng, J. Kelley, J. D. Kish and Y. Liu, J. Phys. Chem. A, 2014, 118, 583-591.

40 H. H. Willard and G. F. Smith, J. Am. Chem. Soc., 1923, 45, 286-297.

41 J. D. Toner and D. C. Catling, Geochim. Cosmochim. Acta, 2016, 181, 164-174.

42 J. D. Toner, D. C. Catling and B. Light, Geochim. Cosmochim. Acta, 2015, 166, 327-343.

43 Y. Liu and A. Laskin, J. Phys. Chem. A, 2009, 113, 1531-1538. 